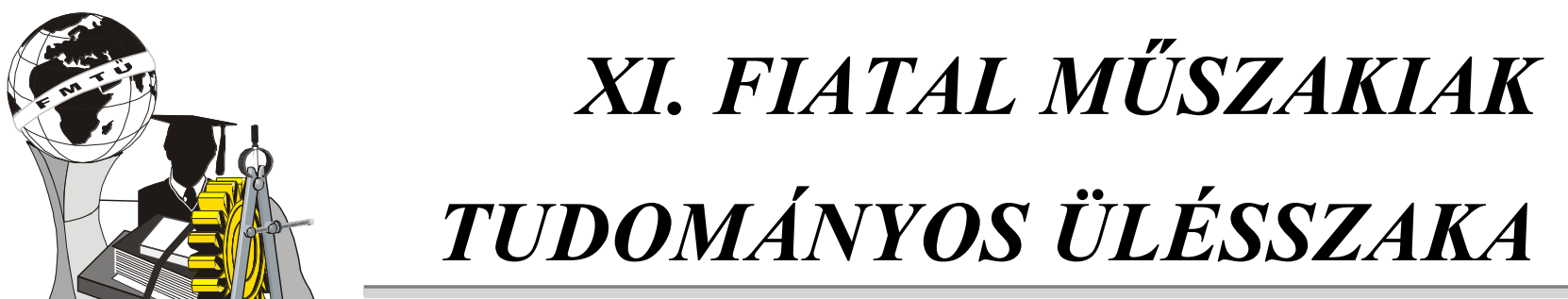

Kolozsvár, 2006. március 24-25.

\title{
ION-EGYKRISTÁLYOK FORGÁCSOLÁSÁNAK SZIMULÁCIÓJA
}

\author{
Dr. Szabó Ottó, Gurzó József
}

\begin{abstract}
With the application of adequate chip separation theories, ultraprecision machining can be planned with better accuracy, more economically and can be better controlled, respectively. For in some cases it is about machining of submicron accuracy (the separated chip cross sectional area is of $\mu m^{2}$ dimension), therefore, traditional cutting theories that describe the separation of the bigger chip-cross sections are not sufficiently accurate. Creation and implementation of new theorises will be needed, such as FEM or finite element method, atomic and molecular dinamical models (MDS). This will be shown in thir paper.
\end{abstract}

\section{Összefoglalás}

Az ultrapontosság igénye a forgácsleválasztás megbízható követését és szabályozását igényli. Az ún. szubmikron pontosságú technológiák (ultraprecíziós forgácsolás, nanotechnológiák) nélkülözhetetlenné váltak. Fémek mellett egyre gyakrabban nem fémes anyagokat (pl. üveg, kerámiák) kell megmunkálni. A leválasztott forgács keresztmetszetek $\mu \mathrm{m}^{2}$ keresztmetszetűek. A forgácsolási folyamatot végeselem (FEM) módszerével, atom és molekuláris dinamikai szimulációval tudjuk csak szimulálni. Az utóbbi módszert mutatjuk be. 


\section{NaCl ion-kristály próba-szimulációja}

Korábban a réz egykristályok forgácsolását molekuláris dinamikai szimuláció (MDS) alkalmazásával vizsgáltuk [3]. A fémkristályokra kidolgozott $\mathrm{MDS}$-t ionkristályok $(\mathrm{NaCl}, \mathrm{KCl}$, stb.) forgácsolásának szimulációjára alkalmassá tettük $[4,5]$.

Vizsgáljuk meg a [4] cikk (6) potenciál függvénye felhasználásával és a [4] cikk 1. ábrája segítségével az $\mathrm{NaCl}$ kristályrács belsejében (21-es ion; térközép), egy kristály felületen (7-es ion; felületközép), egy kristály élen (23-as ion; élközép) és egy kristály sarokpontban elhelyezett (11-es ion; sarok) ion potenciális energiájának alakulását.

Az 1. ábrán láthatjuk, hogy a 3x3x3-as kristályrács ([4] cikk 1. ábra) középpontjában lévő ion (21-es ion) egyensúlyi helyzete megegyezik az elméleti helyzettel ( $x=2,81 \mathrm{e}-10 \mathrm{~m} ; \mathrm{y}=2,81 \mathrm{e}-10 \mathrm{~m}$; $\mathrm{z}=2,81 \mathrm{e}-10$ m). Ez azt jelenti, hogy a szimuláció megindítása után az eredeti helyre generált 21-es ion egyéb erőhatások nélkül (pld. gyémántszerszámmal forgácsolás) az egyensúlyi rezgéshely körül fog rezegni. Látható, hogy az egyensúlyi helyzetben $-1,18^{*} 10^{-18} \mathrm{~J}$ a vizsgált ion potenciális energiája a megfigyelt kristályrácsban, míg az elméleti úton kapotté $-1,28 * 10^{-18} \mathrm{~J}$. A különbség annak tudható be, hogy az 1 . ábra eredménye nem végtelen sok ion, hanem „csak” 26 szomszéd figyelembevételével készült (egyébként ez jó közelítés). 




1. ábra Az NaCl kristály belsejében lévö ion potenciális energija

(21-es ion; térközép)

Hasonlóan megvizsgáltuk a kristályrács egyik lapján (pl. 7-es ion), egyik élén (pl. 23-as ion), illetve egyik sarkán lévő (pl. 11-es) ionokat.

\section{Következtetés ek}

Elméleti úton is megállapítható, de ezt a szimuláció is kimutatta, hogy a szimuláció kezdetén generált ideális kristályrács egyéb erőhatások nélkül is elkezd a külső felületein tágulni, ami maga után vonja a belső felületek kifelé történő elmozdulását is. Láthatjuk továbbá a figyelembe vett ionszámokból, az elméleti és számított potenciális energiák különbségéből, hogy eltérések tapasztalhatóak. Feltételezésünk szerint a figyelembe vett szomszédok száma nagymértékben befolyásolja az eredményt. Amikor több szomszédot vettünk figyelembe a számítás során, akkor pontosabb és stabilabb eredményeket kaptunk. 
A kutatást az OTKA T48760 (témavez.: Szabó O.); az OTKA F019105 (témavez: Gurzó J.), és az OTKA T030668 (témavez: Szabó O.) (Budapest) támogatásával végeztük, illetve folyatjuk.

\section{Irodalomjegyzék}

[1] CHARLES, K.: Introduction to Solid States Physics, Second Edition, John Wihley \& Sons, Inc. New York - - London, 1963., 70. oldal - 84. oldal.

[2] BERECZ, E.: Fizikai kémia, Második kiadás, Tankönyvkiadó, Budapest, 1988., 183-185. oldal.

[3] SZABÓ, O. - GURZÓ, J.: Variation of Temperatur Due to the Glinding of Atomic Planes, 9th International Conference on Tools. Proceedings. Edit. I. Dudás, O. Szabó., Miskolc, 1996., 307 312. oldal.

[4] SZABÓ, O - GURZÓ, J.: Ionkristályok potenciális energiájának számítása mikroforgácsolás szimulációjához, Fiatal Müszakiak Tudományos Ülésszaka, VIII. kötet, Erdélyi Múzeumegyesület kiadványa, Kolozsvár, 2003. 315 - 318. oldal.

[5] GURZÓ, J. - SZABÓ, O.: Ionkristályok mikroforgácsolásának számítógépi próba-szimulációja, Fiatal Műszakiak Tudományos Ülésszaka, VIII. kötet, Erdélyi Múzeumegyesület kiadványa, Kolozsvár, 2003.319 - 322. oldal.

Dr. Szabó Ottó, a műszaki tudomány kandidátusa, Ph.D, egyetemi docens, tudományos vezetó, Miskolci Egyetem, Gépgyártástechnológiai Tanszék, 3515. Miskolc-Egyetemváros. e-mail: ggytszo@gold.uni-miskolc.hu Tel: +36-46-565-111/15-21

Gurzó József, doktorandusz, okl. gépészmérnök, Sárospataki Precíziósszerszámgyártó Bt. Sárospatak 